\title{
Suture techniques for tendon repair; a comparative review
}

\author{
Shelley Rawson ${ }^{1}$ \\ Sarah Cartmell ${ }^{1}$ \\ Jason Wong ${ }^{2}$ \\ 1 Material's Science Centre, University of Manches- \\ ter, UK \\ 2 Plastic Surgery Research, University of Manches- \\ ter, UK
}

Corresponding author:

Sarah Cartmell

Materials Science Centre, University of Manchester

Grosvenor Street

Manchester, UK

M1 7HS

E-mail: sarah.cartmell@manchester.ac.uk

\section{Summary}

Over the past five decades we have seen numerous iterations of suture repair methods for tendon. The pursuit of the ultimate repair has led to many repair methods being described. This comprehensive compilation of the suture repair techniques will describe the factors that affect repair success, including repair strength, gapping resistance, glide and rehabilitation. Different approaches to rejoining severed tendons will be critiqued on their biomechanical ability to improve tendon repair strength, maintaining glide, reducing tendon damage, and minimising adhesion formation. It is important to highlight how the suture repairs have evolved and improved but also review how they may contribute to their own trauma. The apparent paradox between providing mechanical strength and minimising adhesions require refinements in the field to improve on functional outcomes.

KEY WORDS: adhesion, glide, repair, strength, suture, tendon.

\section{Introduction}

Over 30,000 people suffer tendon injury in the UK per annum and over two thirds of these are hand tendon injuries ${ }^{1}$. Hand tendon lacerations are notoriously difficult to treat with over $25 \%$ of patients achieving an unsatisfactory clinical outcome as assessed by the clinician, and $7.7 \%$ of repairs re-rupture, requiring further surgery ${ }^{2}$. Tendons are commonly repaired using suture, and many different suture configurations have been described for tendon repair. Despite many in vivo clinical studies and ex vivo tensile tests comparing different suture techniques, a variety of different repair methods are employed in the clinical setting, indicating that there is currently no unified technique for tendon repair.

The techniques which have dominated tendon repair to date have been compiled in this review to evaluate the merits of the various repair techniques. We consider historical controversies and issues facing the present day clinician, and review current trends and future directions for tendon repair methods that will hopefully improve on current repair design.

\section{History: primary repair}

In 1918, Bunnell described his experiences in attempting primary repair of severed flexor tendons in Zone II of the finger. Adhesions formed as the repair healed, resulting in total loss of movement in the digit. Primary repair was deemed unsuitable which led to recommendations to graft, principally to regain finger function ${ }^{3}$.

The trend for autograft repair for Zone II tendon lacerations changed in the 1960's after Verdan reported comparable results from primary repair, in cases with minimal damage to the tendon ends ${ }^{4}$. Stainless steel transfixion pins immobilised the tendon for three weeks and function was regained by passive mobilisation ${ }^{4}$. Primary tendon repair using suture became, and remains, the method of choice for repair of Zone II severed tendons ${ }^{5}$.

\section{History: tendon mobilisation}

In contrast with the widely accepted protocol of an initial rest period advised by Bunnell ${ }^{3}$, Lister et al. reported the use of early passive mobilisation to induce relative motion between the tendon and sheath and ultimately reduce restrictive adhesions ${ }^{6}$. Clinical outcome was encouraging and the technique was widely adopted. The place and hold technique was introduced in 1993, involving passive flexion, followed by the patient actively maintaining finger position which provided improved clinical outcome compared with passive mobilisation. Further to the success of early passive mobilisation, methods of early active mobilisation were developed whereby the finger is actively flexed and extended. Clinical studies investigating early active mobilisation reported superior range of 
motion at 6 postoperative months compared with passive mobilisation?.

Early active mobilised tendons exhibited improved strength throughout healing, and reduced adhesion formation compared with immobilised tendons in a canine flexor digitorum profundus (FDP) in vivo study ${ }^{8}$. The proposed mechanism of this is that physiological forces promote gene expression of type 1 collagen formation during healing and that tension causes the collagen to be deposited and aligned in a parallel fashion ${ }^{9}$. This is supported by further studies reporting improved strength and gapping resistance ${ }^{8}$ and reduced adhesion formation ${ }^{10}$. Up-regulation in inflammatory gene expression was observed in unloaded compared with mobilised healing in rat Achilles tendon ${ }^{11}$. Inflammatory gene expression due to immobilisation may cause the mechanical integrity of tendon tissue to deteriorate ${ }^{12}$, which agrees with studies showing greater strength in early mobilised tendons ${ }^{8}$. Although it is agreed that early active mobilisation reduces adhesions, few other modalities appear to impact adhesion formation for clinical benefit. There remains a perception that the severity of adhesions is governed by the relative contribution between neovascularisation via surrounding tissue or via the cut ends of the tendon, termed extrinsic and intrinsic healing respectively ${ }^{13}$.
Observations in a murine model demonstrated that intrasynovial tendon healing cannot be considered in isolation since surrounding tissues also sustain damage. Adhesions occur due to cell migration and proliferation out of the damaged tendons, and the surrounding tissues across a soluble gradient ${ }^{14}$. Tendon healing therefore does not suffer from early active mobilisation since the direction of collagen deposition is realigned in the direction of collagen fibres. This increases the repair strength instead of producing adhesions, provided the gap between the repair is not too large.

\section{Tendon suturing techniques}

There are a number of factors that have been shown to affect the outcomes of tendon repair. The repair strength is the most important factor as the main function of the tendon is to transmit force, hence a repair must withstand the high forces applied by early active mobilisation ${ }^{15}$. This has led to an abundance of different suturing techniques described in the literature, with most focusing on improving repair strength, each fostering further iterations of the more successful techniques (Fig. 1).

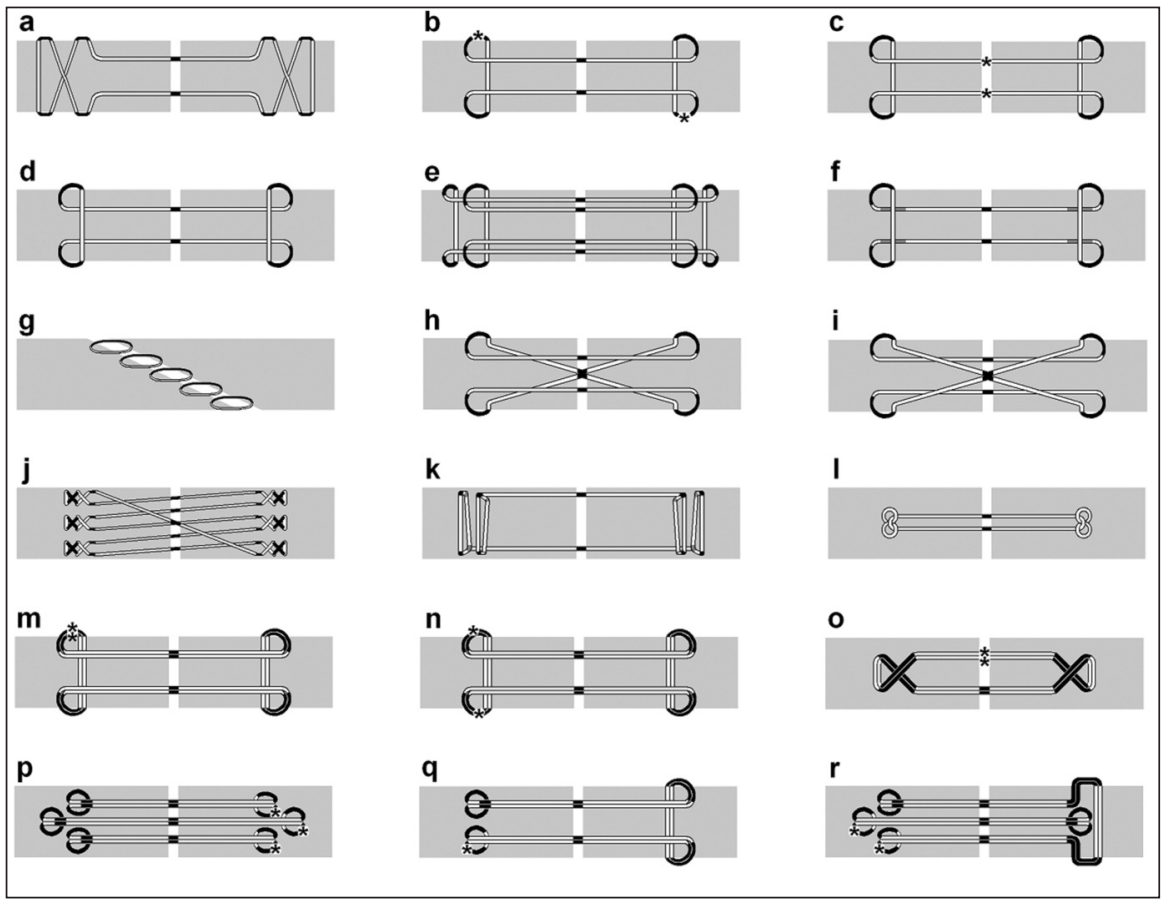

Figure 1. Some of the joining techniques described in literature. Light Grey = Tendon. White = Suture internal of tendon. Black = suture external of tendon. Dark Grey = Suture external of tendon, dorsally placed (Only shown on figures $f$ and $k$ ). ${ }^{*}=$ placement of knot (only shown on figures b, $c$ and $m$ to $r$ ). Double strand suture used in repairs $m$ to $r$. Adapted from ${ }^{8,16-20}$. $a$. Bunnell; 2 strand, non-grasping anchor. b. Grasping Kessler; 2 strands, grasping anchor. c. Tajima; 2 strands, grasping anchor. d. Modified locking Kessler (aka. Pennington); 2 strand, locking anchor. e. Four strand double modified Kessler; 4 strands, locking anchor. f. Modified Pennington; 2 strand, locking anchor. g. Becker; Interrupted stitch joining oblique tendon ends. h. Grasping Cruciate; 4 strand, grasping anchor. i. Locking Cruciate; 4 strand, locking anchor. j. Savage; 6 strand, xstitch anchor. k. Locking Lee; 2 strand, locking anchor with large purchase. I. Tsuge; 2 strand, anchor buried within tendon. $\mathbf{m}$. Four strand Kessler repair. $\mathbf{n}$. Four strand Kessler repair with knots on opposing sides. $\mathbf{0}$. Four strand cross-lock repair. p. Tang. q. U-shaped four strand repair $\mathbf{r}$. Six strand M-tang. 
Another factor is prevention of gapping in order to permit healing. Gelberman et al. demonstrated in vivo that $3 \mathrm{~mm}$ is the maximum permissible gap to allow tendon healing ${ }^{21}$ and gaps larger than this not only increased rupture rates but also impaired range of motion. It appears that the gap is sufficient to allow migration of tendon fibroblasts into the surrounding tissues during healing which ultimately impacts on glide $^{22}$ and repair strength ${ }^{23}$. The other factors lie with respecting the biology of tendon. In the interest of reducing adhesions, Bunnell's philosophy of minimal handling, and care to avoid vascular interference must also be observed ${ }^{24}$. Paradoxically this means current mulistrand repair techniques which are stronger and gap resistant, are detrimental to glide and cause increased tissue trauma.

Studies comparing the relative merits of several techniques have been well documented (Tab. 1). However, due to a lack of consistency in the methods of investigation, these studies are not easily comparable. A compromise must be made between the level of complexity of a repair and the strength it provides (Fig. 2).

\section{Number of core sutures and anchor points}

In 1985 Savage described a technique using six core sutures sharing the load over six anchor site and these compelling ex vivo results initiated the trend for multistrand repairs. During ex vivo tensile testing using porcine samples, the Savage technique withstood $6.85 \mathrm{~kg} \pm 1.346(67.13 \mathrm{~N})$ which was significantly stronger than the next strongest technique, Bunnell, which failed at $2.3 \mathrm{~kg}(22.54 \mathrm{~N})^{25}$. Increased core sutures and anchor points significantly improves strength and gapping resistance ${ }^{29}$. This has led to a culture of multistrand tendon repairs which are undoubtedly stronger but add to operative time and tissue trauma which may have implications to the tendon healing biology.

Maintaining glide between the tendon and sheath is also of great importance when considering an ideal tendon repair. Undamaged human tendons required $0.021 \mathrm{~N}$ to $0.31 \mathrm{~N}$ force to permit movement in a cadaver hand study ${ }^{30}$. The force required for movement is significantly greater in a repaired tendon due to oedema, damage to the gliding surfaces, and presence of the repair itself 23 . In general, more core sutures adversely affect glide, as do externally placed anchor points, or externally placed knots ${ }^{31}$. Gliding resistance of two strand repairs performed on cadaver hand tendons ranged from $0.79 \mathrm{~N}( \pm 0.16)$ to $1.06 \mathrm{~N}$ $( \pm 0.17)^{27}$. In a canine ex vivo study, whilst undamaged tendons presented $0.09 \mathrm{~N}$ gliding resistance, that of repaired tendons ranged from $0.33 \mathrm{~N}( \pm 0.02)$ for a running circumferential suture to $0.86 \mathrm{~N}( \pm 0.24)$ for a 4 strand modified Savage and $0.86 \mathrm{~N}( \pm 0.32)$ for the Becker stitch ${ }^{31}$.

Repairs which possess more anchor points and suture strands are often more complex to perform and require more time, handling and skill to ensure re- peatability ${ }^{32}$. These factors may deter the clinician from using such repair techniques, particularly when you consider approximately $25 \%$ of patients sustain multiple flexor tendon injuries ${ }^{2}$. Methods to reduce handling, tendon puncture and have the benefits of multistrand repair have been offered by using double strand sutures, inciting the development of new repair techniques (Fig. 1 m-r) (34).

\section{Non-grasping, grasping and locking}

Suture anchoring has a significant impact on the strength of the repair ${ }^{27}$. Tendon's high tensile strength is attributed to its hierarchical arrangement of long parallel collagen fibres encased in a tough smooth layer, known as the epitenon ${ }^{30}$. This is a biologically active layer that provides purchase strength but also prevents cells migrating out of the tendon ${ }^{33}$. Repairs which possess greater failure strength better exploit the aligned structure of the tendon and the high strength of the fibres and epitenon.

The strength of a given repair is attributed to how effectively it transmits axial tension into grip onto the tendon fibre bundles. Initial methods employed a nongrasping anchor aligned perpendicular to the fibre bundles, looped around a small portion of the epitenon (Fig. 3-a) such as the Bunnell technique. Upon failure the suture cuts between the fibres, thus the strength of the fibres is not exploited. The grasping method of anchoring, used in the grasping Kessler and Tajima techniques, has a suture loop around the epitenon and fibres. The loop tightens as the load is increased, which pinches onto the fibres (Fig. 3-b). The locking anchor improves on this method by creating a closed loop (Fig. 3-c) as employed in the locking Kessler and Locking Lee sutures. The loop acts like a noose and tightens around the enclosed portion of fibres, thus resulting in a much more effective anchor ${ }^{17}$.

The locking Kessler withstood $38.7 \mathrm{~N} \pm 5.1$ demonstrating superior strength when compared with the grasping Kessler which withstood $33.7 \mathrm{~N} \pm 4.7$ during an ex vivo cadaver FDP study by Tanaka et al. The anchor method had no effect on gliding if the amount of external suture is equal in the two given anchor methods ${ }^{27}$. The modified Pennington suture was designed to improve ease and reliability of producing a locking loop by having part of the core suture pass external of the tendon (Fig. $3-d)^{18}$. Whilst this improves repair reproducibility, it increases trauma and external sutures which may encourage adhesions and inhibit glide.

It has also been observed that one key factor for augmenting tendon repair strength is the distance of the anchors away from the repair site. Studies have shown that a larger purchase through the tendon greatly increases repair strength on the basis that damaged tendon ends and the zone of trauma is likely to soften over subsequent days ${ }^{34}$.

Ultimately, despite the increased strength attainable by improved anchor methods, the main determinant 
Table 1. Ex vivo studies of suturing techniques under axial tensile load.

\begin{tabular}{|c|c|c|c|c|c|c|}
\hline Name & Suture & Epitenon suture & Test Tissue & $\begin{array}{l}\text { Force at } \\
\text { fail }(N)\end{array}$ & $\begin{array}{c}\text { load to } \\
2 \mathrm{~mm} \text { gap } \\
\text { (N) }\end{array}$ & Reference \\
\hline Bunnell & 4-0 Ethibond & none & pig & 22.563 & 15.696 & Savage, $1985^{25}$ \\
\hline \multirow{6}{*}{$\begin{array}{l}\text { Grasping } \\
\text { Kessler }\end{array}$} & 4-0 Ethibond & none & pig & 19.62 & 3.924 & Savage, $1985^{25}$ \\
\hline & 4-0 Dracon & none & $\begin{array}{l}\text { human } \\
\text { cadaver }\end{array}$ & 22.09212 & & Lee, $1990^{19}$ \\
\hline & $\begin{array}{c}\text { 4-0 nylon } \\
\text { nonabsorbable }\end{array}$ & 6-0 nylon running & $\begin{array}{c}\text { Human } \\
\text { cadaver finger }\end{array}$ & $\begin{array}{c}23.8 \\
(\text { SEM1.6) }\end{array}$ & & Noguchi et al., $1993^{26}$ \\
\hline & $\begin{array}{c}\text { 4-0 nylon } \\
\text { nonabsorbable }\end{array}$ & 6-0 nylon running & $\begin{array}{l}\text { Canine flexor } \\
\text { digitorum }\end{array}$ & $\begin{array}{c}26 \\
(\text { SEM2.4) } \\
\end{array}$ & & Noguchi et al., $1993^{26}$ \\
\hline & $\begin{array}{l}\text { 4-0 looped } \\
\text { (supramid) }\end{array}$ & $\begin{array}{l}\text { 6-0 nylon (ethicon) } \\
\text { running suture }\end{array}$ & $\begin{array}{c}\text { human } \\
\text { cadaver finger }\end{array}$ & $\begin{array}{c}33.7 \\
(\mathrm{SD} 4.7)\end{array}$ & $\begin{array}{c}30.3 \\
\text { (SD8.6) }\end{array}$ & Tanaka et al., $2004^{27}$ \\
\hline & 4-0 Ethibond & $\begin{array}{l}\text { 6-0 Ethilon } \\
\text { circumferential } \\
\text { locking suture }\end{array}$ & $\begin{array}{l}\text { human } \\
\text { cadaver }\end{array}$ & $\begin{array}{c}31 \\
\text { (SD7) }\end{array}$ & & Barrie et al., $2001^{28}$ \\
\hline Tajima & $\begin{array}{c}\text { 4-0 nylon } \\
\text { nonabsorbable }\end{array}$ & 6-0 nylon running & $\begin{array}{c}\text { human } \\
\text { cadaver finger }\end{array}$ & $\begin{array}{c}30.5 \\
(\text { SEM1.9) }\end{array}$ & & Noguchi et al., $1993^{26}$ \\
\hline $\begin{array}{l}\text { Modified } \\
\text { Kessler } \\
\text { Locking }\end{array}$ & $\begin{array}{c}4-0 \\
\text { polypropylene } \\
\text { monofilament } \\
\text { core suture }\end{array}$ & none & sheep & $\begin{array}{c}34.44 \\
\text { (SD2.33) }\end{array}$ & $\begin{array}{c}22.56 \\
\text { (SD3.44) }\end{array}$ & Dogramaci et al., $2008^{29}$ \\
\hline \multirow[t]{2}{*}{$\begin{array}{c}\text { AKA } \\
\text { Pennington }\end{array}$} & 4-0 Ethibond & $\begin{array}{c}\text { 6-0 Ethilon } \\
\text { circumferential } \\
\text { locking suture }\end{array}$ & $\begin{array}{l}\text { human } \\
\text { cadaver }\end{array}$ & $\begin{array}{c}32 \\
\text { (SD9) } \\
\end{array}$ & & Barrie et al., $2001^{28}$ \\
\hline & $\begin{array}{l}\text { 4-0 looped } \\
\text { (supramid) }\end{array}$ & $\begin{array}{l}\text { 6-0 nylon (ethicon) } \\
\text { running suture }\end{array}$ & $\begin{array}{c}\text { human } \\
\text { cadaver finger }\end{array}$ & $\begin{array}{c}38.7 \\
(\mathrm{SD} 5.1) \\
\end{array}$ & $\begin{array}{c}32.5 \\
(\mathrm{SD} 5.3)\end{array}$ & Tanaka et al., $2004^{27}$ \\
\hline $\begin{array}{l}\text { Four- } \\
\text { strand } \\
\text { double- } \\
\text { modified } \\
\text { Kessler }\end{array}$ & $\begin{array}{l}\text { 4-0 } \\
\text { polypropylene } \\
\text { monofilament } \\
\text { core suture }\end{array}$ & none & sheep & $\begin{array}{c}53.38 \\
\text { (SD8.09) }\end{array}$ & $\begin{array}{c}30.85 \\
\text { (SD1.90) }\end{array}$ & Dogramaci et al., $2008^{29}$ \\
\hline $\begin{array}{l}\text { Modified } \\
\text { Pennington }\end{array}$ & $\begin{array}{l}\text { 4-0 looped } \\
\text { (supramid) }\end{array}$ & $\begin{array}{l}\text { 6-0 nylon (ethicon) } \\
\text { running suture }\end{array}$ & $\begin{array}{c}\text { human } \\
\text { cadaver finger }\end{array}$ & $\begin{array}{c}48 \\
\text { (SD3.9) }\end{array}$ & $\begin{array}{c}40.5 \\
\text { (SD5.5) }\end{array}$ & Tanaka et al., $2004^{27}$ \\
\hline Becker & 6-0 Prolene & none & pig & 12.753 & $\begin{array}{c}\text { no gap } \\
\text { up to } \\
\approx 12.753 \text {, } \\
\text { then } \\
\text { failure }\end{array}$ & Savage, $1985^{25}$ \\
\hline $\begin{array}{l}\text { Grasping } \\
\text { Cruciate }\end{array}$ & 4-0 Ethibond & $\begin{array}{l}\text { 6-0 Ethilon } \\
\text { circumferential } \\
\text { locking suture }\end{array}$ & $\begin{array}{l}\text { human } \\
\text { cadaver }\end{array}$ & $\begin{array}{c}46 \\
\text { (SD12) }\end{array}$ & & Barrie et al., $2001^{28}$ \\
\hline $\begin{array}{l}\text { Locking } \\
\text { Cruciate }\end{array}$ & 4-0 Ethibond & $\begin{array}{l}\text { 6-0 Ethilon } \\
\text { circumferential } \\
\text { locking suture }\end{array}$ & $\begin{array}{l}\text { human } \\
\text { cadaver }\end{array}$ & $\begin{array}{c}49 \\
\text { (SD13) }\end{array}$ & & Barrie et al., $2001^{28}$ \\
\hline Savage & 4-0 Ethibond & none & pig & 67.1985 & 44.145 & Savage, $1985^{25}$ \\
\hline \multirow[t]{3}{*}{$\begin{array}{l}\text { Locking } \\
\text { Lee }\end{array}$} & 4-0 Dracon & none & $\begin{array}{l}\text { human } \\
\text { cadaver }\end{array}$ & 43.164 & & Lee, $1990^{19}$ \\
\hline & $\begin{array}{l}\text { 4-0 polyester } \\
\text { fiber suture }\end{array}$ & 6-0 nylon running & $\begin{array}{c}\text { human } \\
\text { cadaver finger }\end{array}$ & $\begin{array}{c}37.6 \\
(\text { SEM1.5) } \\
\end{array}$ & & Noguchi et al., $1993^{26}$ \\
\hline & $\begin{array}{l}\text { 4-0 looped } \\
\text { (supramid) }\end{array}$ & $\begin{array}{l}\text { 6-0 nylon (ethicon) } \\
\text { running suture }\end{array}$ & $\begin{array}{c}\text { human } \\
\text { cadaver finger }\end{array}$ & $\begin{array}{c}41 \\
\text { (SD3.5) } \\
\end{array}$ & $\begin{array}{c}37.4 \\
\text { (SD9) }\end{array}$ & Tanaka et al., $2004^{27}$ \\
\hline Tsuge & $\begin{array}{l}\text { 4-0 polyester } \\
\text { fiber suture }\end{array}$ & 6-0 nylon running & $\begin{array}{c}\text { human } \\
\text { cadaver finger }\end{array}$ & $\begin{array}{c}27.3 \\
\text { (SEM1.4) }\end{array}$ & & Noguchi et al., $1993^{26}$ \\
\hline
\end{tabular}

$\mathrm{SD}=$ Standard deviation. SEM $=$ Standard error. 


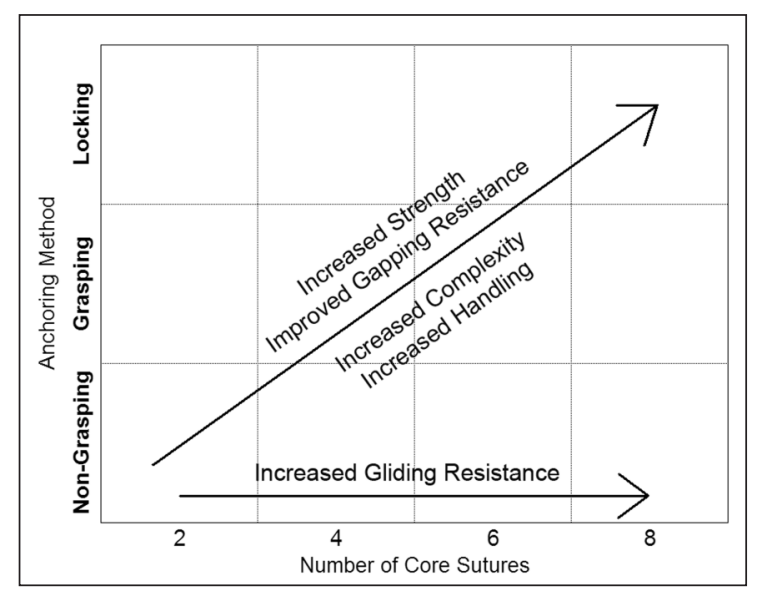

Figure 2. General relationship between different suturing techniques and strength, gapping resistance, complexity, handling and gliding resistance.

remains the strength of the core sutures. However, present suture techniques have a limit to how much load can be transmitted across the limited cross sec- tional area of the sutures. There remains scope for improvements in axial strength and anchoring strength by altering repair design.

\section{Internal vs external}

An abundance of external suture increases gliding resistance, as demonstrated by Angeles et al. who evaluated the relative merits of six different suturing techniques using cadaver hands ${ }^{35}$. Suture knot location also affects glide. The Tajima repair, whose knot is internal, exhibits significantly lower gliding resistance than Kessler which is identical except for an externally placed nnot $^{26}$. The contrary argument is that knot placement between the cuts should be avoided as this reduces the tendon end contact surface area that is involved in healing ${ }^{24}$.

Typically, repairs with greater strength tend to pose greater gliding resistance, with the exception of the Tsuge repair which has little externalised suture. A modification of the Tsuge repair withstood $60.3 \mathrm{~N}$ \pm 15.3 during ex vivo tensile testing of cadaver FDP

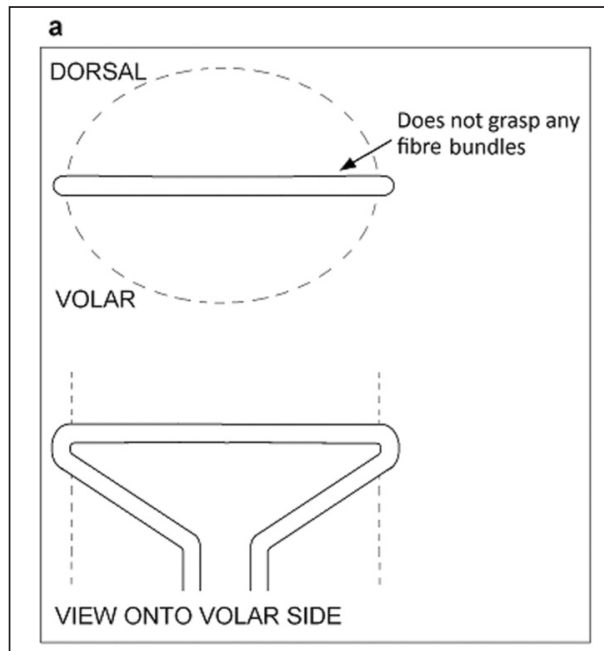

c

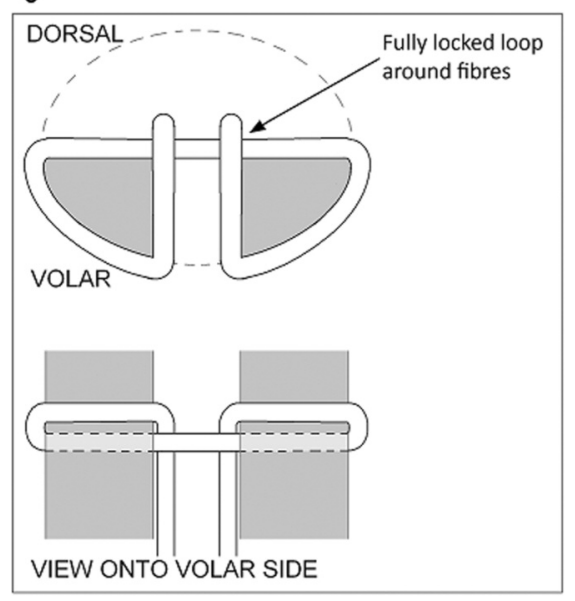

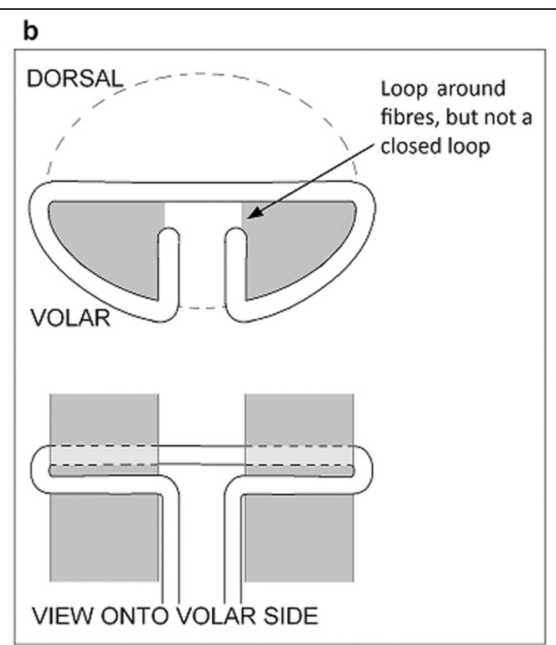

d

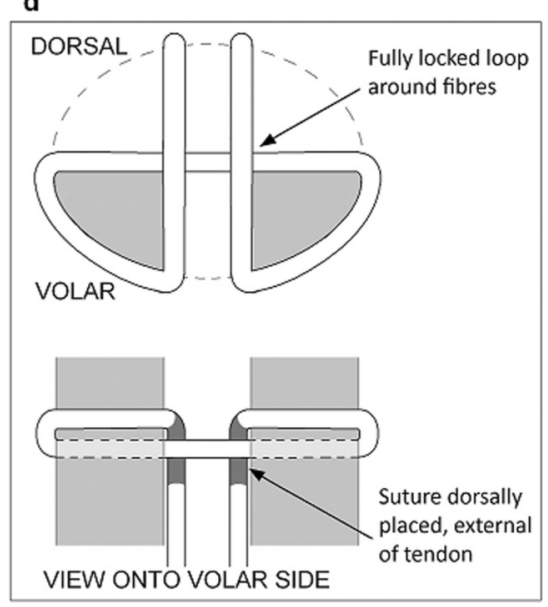

Figure 3. Four different suture anchoring methods. The portion of tendon fibres that the suture anchors around is shown in dark grey. The tendon outline is shown as a dashed in the cross sectional views. Dark grey represents suture which passes outside the tendon on the dorsal side. a. Non-grasping b. Grasping. c. Locking (aka. Pennington Lock) d. Modified Pennington Lock 
tendons, and posed the least resistance to glide of the six repairs tested ${ }^{35}$. However, internal suture placement is controversial as healing may be impaired by vascular interference and trauma to the tissue ${ }^{24}$.

In recent years, novel repair techniques have emerged using both entirely internal and entirely externally placed material. Dorsal and internal placement of a dacron splint was considered, which withstood $8.10 \mathrm{~kg}(79 \mathrm{~N})$ and $8.46 \mathrm{~kg}(83 \mathrm{~N})$ respectively in a human cadaver flexor tendon study. The entirely external dorsal splint repair provided superior gapping resistance over traditional suture repairs ${ }^{36}$, however, this technique has not received widespread use. Greater interest was received by the Teno Fix device, which is a stainless steel repair, fully embedded within the tendon. During clinical evaluation, none of the 34 Teno Fix repairs ruptured during active mobilisation ${ }^{2}$. However, the device is relatively expensive, only suited to tendons of adequate size, where adequate surgical exposure is possible ${ }^{2}$, and where there is minimal damage to the tissue ${ }^{37}$. The lack of uptake of these two widely different approaches for tendon repair demonstrates that the hand community remain uncomfortable with using devices to repair tendon.

\section{Peripheral circumferential suture}

The use of a peripheral circumferential suture in addition to a core suture was recommended by Mason and Shearon to ensure the ends meet laterally ${ }^{24}$. Circumferential sutures are now commonplace in the repair of tendon and have been shown to enhance both mechanical strength and gapping resistance ${ }^{38}$.

Many circumferential sutures have been defined in the literature. Six circumferential suture techniques were comprehensively tested by Kubota et al., which were, in ascending order of strength; Simple locking, Simple, Lembert, Halstead, Cross-stitch and Lin-locking $^{39}$. In general, gapping resistance and tensile strength increases with increasing number of suture strands across the join ${ }^{39}$. However, as we have previously encountered, a complex repair is less desirable during surgery ${ }^{32}$. Furthermore, the strongest technique, 18 strand Lin Locking, possessed almost twice the strength of the next strongest, however, it also presented a $33.5 \% \pm 10.1$ to $36.8 \% \pm 13.6$ increased gliding resistance compared with healthy tendon, significantly greater than all other methods ${ }^{39}$.

Whilst the use of circumferential suture is now commonplace, the method of choice is not standardised, owing to the compromise between strength and gapping resistance against glide and complexity.

\section{Complications of tendon repair}

The main complications following tendon repair are rupture and adhesion formation. Unfortunately, two of the major factors over which we have control in our management, strength of repair and mobilization, are at odds with each other with regards to risk of rupture and adhesion formation. Those that contribute to rupture discourage adhesion formation and vice versa.

Early mobilization is paramount in order to obtain good functional glide however if the strength of repair is not adequate the risk of rupture is increased. Without mobilization rupture is less likely but adhesions are more likely to form. Hence focus on tendon repair is on having a high repair strength in order to survive early active mobilization and avoid both rupture and adhesion formation.

Currently our only way of increasing the strength of a repair is by putting in more suture material both in the core and circumferentially. It has been demonstrated that more strands of suture and greater caliber of suture both increase the strength of the repair and hence mitigate against rupture ${ }^{40}$. However it has also been shown that more suture material on the outside of the tendon encourages adhesion formation ${ }^{31}$ and that suture material encourages inflammation, which has also been implicated in the formation of adhesions, albeit in the context in infection. The authors have also used an experimental model to show that a single suture and immobilization of tendon encourage adhesion formation (Fig. 4). While more suture material inside the tendon (core suture) has been demonstrated to increase bulk, biomechanical and histological investigation has not shown it to have an effect on gliding or adhesion formation, using 2 vs 6 strand in vitro ${ }^{41}$ and 2 vs 4 strand in vivo ${ }^{42,} 43$ models.

Other contributors to failure are suture pull out and gap formation. Various locking and grasping loop configurations have been described but have not been convincingly demonstrated to confer any advantage in terms of pull out or gapping 44 .

In essence, the challenge we face is that more extensively sutured, less mobile repairs are less likely to rupture, while repairs with less suture material that are mobilized are less likely to form adhesions.

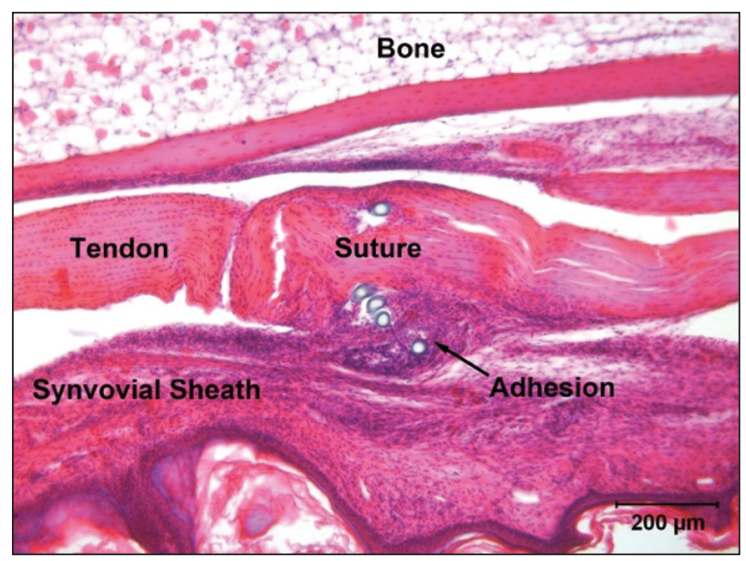

Figure 4. A single suture in an immobilized mouse digital flexor tendon, showing the resultant adhesion. Scale bar 200 microns. 


\section{The mechanism of suture induced tendon damage}

The ultrastructure of tendon is highly organized with tenocytes constantly producing and arranging collagen in a regular pattern and interacting with one another through cytokine and growth factor signaling but also through gap junctions, primarily connexins 32 and $43^{45}$, in differing ways throughout the tendon 46 . For this reason the cellular organization in tendon is as important as the organization of extracellular matrix components. Mechanotransduction through this system results in increased collagen synthesis and arrangement of collagen fibrils along axes of strain and is necessary for remodeling after injury 47,48 .

It has been shown that the process of suturing tendon causes cell death directly ${ }^{49}$. A single suture animal model has revealed the formation of an acellular zone that forms around suture within 72 hours and persists for at least 1 year. This acellular zone forms as a result of tension placed across suture grasp. The effect is lessened without this tension.

Wong et al. reported acellular regions within the tendon when internal suture is present and tension is applied during a study of the cell response to a grasping suture in a murine model. Healing was not observed in acellular zones, and prolonged inflammation occurred at the sites of placed suture, which potentially stimulates adhesion formation ${ }^{50}$. Similar work comparing different suturing techniques would be of interest to consider whether inflammation and the acellular region are more severe in specific repair methods. The clinical relevance of these findings is that cell death, inflammation and extracellular matrix breakdown are occurring most dramatically at the areas of highest stress in repairs, i.e around the locking and grasping throws, which could potentially explain the pathophysiology of many cases of rupture and adhesion formation.

\section{Discussion}

Divided tendons are sutured to re-approximate the tendon ends and permit healing. Successful tendon repair provides sufficient strength, permits glide and results in minimal adhesions. Recent focus has been to increase repair strength in response to more rigorous rehabilitation techniques. Tensile testing and clinical studies have sought to compare different suturing techniques, often focussing on strength, gapping resistance, glide and resultant mobility.

Primary repair has been widely used to reunite severed tendons since the 1960's and in recent years early active mobilisation has been accepted as the ideal rehabilitation method. However, disagreement remains regarding suture technique and specific rehabilitation exercises. Traditional tendon sutures employed two core strands bridging the gap between the tendon ends. Increasing the number of core sutures and anchor points increases strength and permits more rigorous rehabilitation without risk of rupture, which potentially benefits adhesion reduction. However, it also adds bulk to the repair site which increases gliding resistance. Improving the anchor method increases strength without detriment to glide, however, if the repair only possesses two core sutures the ultimate repair strength will remain limited. Entirely internal repairs possess lower gliding resistance, but there are concerns over acellularity and ischemia with internal suture placement.

Addition of a peripheral circumferential suture is now commonplace to ensure the tendon ends meet laterally and to provide additional strength and gapping resistance. Like the core suture, there are many different peripheral suture techniques, and those which provide greater strength also pose greater resistance to glide. Techniques to improve one aspect of a repair often pose detriment to other requirements and a compromise must be sought. It is arguable that disagreement regarding best practice techniques paves the way for innovation and improvements, however, in this circumstance the wealth of conflicting information and diverse array of repair techniques may incite confusion. A resolution to current paradoxes of tendon repair may enable improved clinical outcome and a common consensus on a best practice repair technique.

\section{References}

1. Clayton RA, Court-Brown CM. The epidemiology of musculoskeletal tendinous and ligamentous injuries. Injury 2008; 39(12):1338-1344.

2. Su BW, Solomons M, Barrow A, Senoge ME, Gilberti M, Lubbers $\mathrm{L}$, et al. Device for zone-II flexor tendon repair. A multicenter, randomized, blinded, clinical trial. J Bone Joint Surg Am 2005; 87(5):923-935.

3. Bunnell $\mathrm{S}$. Repair of tendons in the fingers and description of two new instruments. Gynecology and Obstetrics 1918; 26:103-110.

4. Verdan C. Primary repair of flexor tendons. J Bone Joint Surg Am 1960; (42-A):647-657.

5. Kleinert H, Spokevicius S, Papas N. History of flexor tendon repair. Journal of Hand Surgery-American Volume 1995; 20A(3):S46-S52.

6. Lister GD, Kleinert HE, Kutz JE, Atasoy E. Primary flexor tendon repair followed by immediate controlled mobilization. $J$ Hand Surg Am 1977; 2(6):441-451.

7. Baktir A, Türk CY, Kabak S, Sahin V, Kardaş Y. Flexor tendon repair in zone 2 followed by early active mobilization. $J$ Hand Surg Br 1996; 21(5):624-628.

8. Wada A, Kubota H, Miyanishi K, Hatanaka H, Miura H, Iwamoto $\mathrm{Y}$. Comparison of postoperative early active mobilization and immobilization in vivo utilising a four-strand flexor tendon repair. J Hand Surg Br 2001; 26(4):301-306.

9. Davidson CJ, Ganion LR, Gehlsen GM, Verhoestra B, Roepke JE, Sevier TL. Rat tendon morphologic and functional changes resulting from soft tissue mobilization. Med Sci Sports Exerc 1997; 29(3):313-319.

10. Halikis MN, Manske PR, Kubota H, Aoki M. Effect of immobilization, immediate mobilization, and delayed mobilization on the resistance to digital flexion using a tendon injury model. J Hand Surg Am 1997; 22(3):464-472.

11. Eliasson $\mathrm{P}$, Andersson $\mathrm{T}$, Aspenberg $\mathrm{P}$. Rat Achilles tendon 
healing: mechanical loading and gene expression. J Appl Physiol 2009; 107(2):399-407.

12. Uchida $H$, Tohyama $H$, Nagashima $K$, Ohba $Y$, Matsumoto $\mathrm{H}$, Toyama $\mathrm{Y}$, et al. Stress deprivation simultaneously induces over-expression of interleukin-1beta, tumor necrosis factoralpha, and transforming growth factor-beta in fibroblasts and mechanical deterioration of the tissue in the patellar tendon. J Biomech 2005; 38(4):791-798.

13. Potenza $A D$. The healing of autogenous tendon grafts within the flexor digital sheath in dogs. J Bone Joint Surg Am 1964; 46:1462-484.

14. Wong JK, Lui YH, Kapacee Z, Kadler KE, Ferguson MW, McGrouther DA. The cellular biology of flexor tendon adhesion formation: an old problem in a new paradigm. Am J Pathol 2009; 175(5):1938-1951.

15. Schuind F, Garcia-Elias M, Cooney WP, An KN. Flexor tendon forces: in vivo measurements. J Hand Surg Am 1992; 17(2):291-298.

16. Cao Y, Tang JB. A new variant of four-strand tendon repairs. J Hand Surg Eur Vol 2010; 35(6):513-515.

17. Pennington DG. The locking loop tendon suture. Plast Reconstr Surg 1979; 63(5):648-652.

18. Hatanaka H, Zhang J, Manske PR. An in vivo study of locking and grasping techniques using a passive mobilization protocol in experimental animals. J Hand Surg Am 2000; 25(2):260-269.

19. Lee H. Double loop locking suture: a technique of tendon repair for early active mobilization. Part I: Evolution of technique and experimental study. J Hand Surg Am 1990; 15(6):945952.

20. Wu YF, Cao Y, Zhou YL, Tang JB. Biomechanical comparisons of four-strand tendon repairs with double-stranded sutures: effects of different locks and suture geometry. J Hand Surg Eur Vol 2011; 36(1):34-39.

21. Gelberman RH, Boyer MI, Brodt MD, Winters SC, Silva MJ. The effect of gap formation at the repair site on the strength and excursion of intrasynovial flexor tendons. An experimental study on the early stages of tendon-healing in dogs. J Bone Joint Surg Am 1999; 81(7):975-982.

22. Zhao C, Amadio PC, Tanaka T, Kutsumi K, Tsubone T, Zobitz ME, et al. Effect of gap size on gliding resistance after flexor tendon repair. J Bone Joint Surg Am 2004; 86$A(11): 2482-2488$.

23. Amadio PC. Friction of the gliding surface. Implications for tendon surgery and rehabilitation. J Hand Ther 2005; 18(2):112-119.

24. Mason M, CJ S. The process of tendon repair: an experimental study of tendon suture and tendon graft. Archives of Surgery 1932; 25:615-692.

25. Savage R. In vitro studies of a new method of flexor tendon repair. J Hand Surg Br 1985; 10(2):135-141.

26. Noguchi M, Seiler JG, Gelberman RH, Sofranko RA, Woo SL. In vitro biomechanical analysis of suture methods for flexor tendon repair. J Orthop Res 1993; 11(4):603-611.

27. Tanaka T, Amadio PC, Zhao C, Zobitz ME, Yang C, An KN Gliding characteristics and gap formation for locking and grasping tendon repairs: a biomechanical study in a human cadaver model. J Hand Surg Am 2004; 29(1):6-14.

28. Barrie KA, Tomak SL, Cholewicki J, Merrell GA, Wolfe SW. Effect of suture locking and suture caliber on fatigue strength of flexor tendon repairs. J Hand Surg Am 2001; 26(2):340-346.

29. Dogramaci Y, Kalaci A, Sevinç TT, Esen E, Komurcu M, Yanat AN. Does strand configuration and number of purchase points affect the biomechanical behavior of a tendon repair? A biomechanical evaluation using different kessler methods of flexor tendon repair. Hand (NY). 2008; 3(3):266-270.

30. Uchiyama S, Coert J, Berglund L, Amadio P, An K. Method for the measurement of friction between tendon and pulley J Orthop Res 1995; 13(1):83-89.

31. Zhao C, Amadio PC, Zobitz ME, An KN. Gliding characteristics of tendon repair in canine flexor digitorum profundus tendons. J Orthop Res 2001; 19(4):580-586.

32. Lawrence TM, Woodruff MJ, Aladin A, Davis TR. An assessment of the tensile properties and technical difficulties of two- and four-strand flexor tendon repairs. J Hand Surg $\mathrm{Br} 2005 ; 30$ (3):294-297.

33. Taylor SH, Al-Youha S, Van Agtmael T, Lu Y, Wong J, McGrouther DA, et al. Tendon is covered by a basement membrane epithelium that is required for cell retention and the prevention of adhesion formation. PLoS One 2011; 6(1):e16337.

34. Kim JB, de Wit T, Hovius SE, McGrouther DA, Walbeehm ET. What is the significance of tendon suture purchase? The Journal of hand surgery, European volume 2009; 34(4):497502.

35. Angeles JG, Heminger H, Mass DP. Comparative biomechanical performances of 4 -strand core suture repairs for zone II flexor tendon lacerations. J Hand Surg Am 2002; 27(3):508517.

36. Aoki M, Manske PR, Pruitt DL, Larson BJ. Tendon repair using flexor tendon splints: an experimental study. J Hand Surg Am 1994; 19(6):984-990.

37. Rocchi L, Merolli A, Genzini A, Merendi G, Catalano F. Flexor tendon injuries of the hand treated with Teno Fix: mid-term results. J Orthop Traumatol 2008; 9(4):201-208.

38. Dona E, Gianoutsos MP, Walsh WR. Optimizing biomechanical performance of the 4-strand cruciate flexor tendon repair. J Hand Surg Am 2004; 29(4):571-580.

39. Kubota H, Aoki M, Pruitt DL, Manske PR. Mechanical properties of various circumferential tendon suture techniques. J Hand Surg Br 1996; 21(4):474-480.

40. Strickland JW. Development of flexor tendon surgery: twenty-five years of progress. J Hand Surg Am 2000; 25(2):214235.

41. Sanders DW, Milne AD, Johnson JA, Dunning CE, Richards RS, King GJ. The effect of flexor tendon repair bulk on tendon gliding during simulated active motion: an in vitro comparison of two-strand and six-strand techniques. $\mathrm{J}$ Hand Surg Am 2001; 26(5):833-840.

42. Strick MJ, Filan SL, Hile M, McKenzie C, Walsh WR, Tonkin MA. Adhesion formation after flexor tendon repair: a histologic and biomechanical comparison of 2- and 4-strand repairs in a chicken model. J Hand Surg Am 2004; 29(1):1521.

43. Strick MJ, Filan SL, Hile M, McKenzie C, Walsh WR, Tonkin MA. Adhesion formation after flexor tendon repair: comparison of two- and four-strand repair without epitendinous suture. Hand Surg 2005; 10(2-3):193-197.

44. Mashadi ZB, Amis AA. The effect of locking loops on the strength of tendon repair. J Hand Surg $\mathrm{Br} 1991 ; 16(1): 35$ 39.

45. Waggett AD, Benjamin M, Ralphs JR. Connexin 32 and 43 gap junctions differentially modulate tenocyte response to cyclic mechanical load. Eur J Cell Biol 2006; 85(11):11451154.

46. Ralphs JR, Benjamin M, Waggett AD, Russell DC, Messner K, Gao J. Regional differences in cell shape and gap junction expression in rat Achilles tendon: relation to fibrocartilage differentiation. J Anat 1998; 193(Pt 2):215222.

47. Lindsay W, Thomson H. Digital flexor tendons: An experimental study: Part 1. The significance of each component of the flexor mechanism in tendon healing. British Journal of Plastic Surgery 1959; 12:289-316.

48. Matthew CA, Moore MJ. Regeneration of rat extensor dig- 
itorum longus tendon: the effect of a sequential partial tenotomy on collagen fibril formation. Matrix 1991; 11(4):259-268.

49. Wong JK, Cerovac S, Ferguson MW, McGrouther DA. The cellular effect of a single interrupted suture on tendon. J Hand
Surg $\mathrm{Br} 2006$; 31(4):358-367.

50. Wong JK, Alyouha S, Kadler KE, Ferguson MW, McGrouther DA. The cell biology of suturing tendons. Matrix Biol 2010; 29(6):525-536. 